Ивана Божовић

Универзитет у Приштини

са привременим седиштем у Косовској Митровици

Филозофски факултет

Катедра за руски језик и књижевност

bozoviciva@yahoo.com
УДК 94:929:314.743(=161.1)(497.1) Прицкер А. И. https://doi.org/10.18485/slavistika.2020.24.1.21 Информативни прилог примљено 14.04.2020. прихваћено за штампу 21.05.2020.

\title{
АНАТОЛИЈ ИВАНОВИЧ ПРИЦКЕР: БИОГРАФИЈА
}

У раду су приказани основни биографски подаци Анатолија Ивановича Прицкера - pyског емигранта у Краљевини СХС оснивача издавачке куће Народна просвета. Рад се заснива на архивској грађи, која је први пут представљена у научне сврхе (Државни архив Руске Федерације, затим Архив Југославије и Историјски архив града Београда - Република Србија).

Кључне речи: Анатолиј Иванович Прицкер, Народна просвета, адвокатска канцеларија Савић.

The article presents basic biological information about Anatoly Ivanovich Pricker - a Russian expat in the Kingdom of SCS, founder of the publishing house Narodna Prosveta. The work is based on archival material, which was first presented for scientific purposes by the Archives of Yugoslavia and the Belgrade Historical Archive of the Republic of Serbia.

Keywords: Anatoly Ivanovich Pricker, National Education, Savic Law Office.

Анатолиј Иванович, Прицкер издавач и власник предузећа Народна просвета, родио се у породици почасног грађанина Јоне Давидовича Прицкера и његове жене Александре Славине. У Краљевину Срба, Хрвата и Словенца емигрирао је 1922. Испрва у Сомбор, а затим у Нови Сад, где 1923. отвара издавачку кућу Литерарна кюига. Брак са Крунославом Шешевић, склопљен 1922., омогућио је младом Анатолију Ивановичу да оснује издавачко предузеће Народна просвета, које је убрзо постало једно од водећих издавачких кућа у земљи. Старији Анатолијев син - Александар Ивановић, за време рата био је финансијер војске Драгољуба Драже Михаиловића. А.И.Прицкер и његова породица напустили су Југославију 1946. бежећи од оптужбе за сарадњу са окупатором, и тек 2016. Врховни суд Србије потврдио је његову потпуну рехабилитацију. Адвокатској канцеларији Савић припада огромна заслуга у том процесу.

1920. бежећи од бољшевичког терора, млади руски емигрант Анатолиј Иванович Прицкер долази у Краљевину СХC, о чему сведочи документ Кримске евакуације. ${ }^{1}$ Према расположивим подацима, он се испрва настањује у Сомбору и нешто касније 27. марта 1922, жени се Крунославом Шешевић, девојком која је потицала из угледне и добростојеће породице (од оца Светозара и мајке Василије, рођ.Мађарев), која је била у блиском сродству са Гаврилом Принципом. Кратко су боравили у Новом Саду да би се већ наредне године (1923) Крунослава и Анатолиј преселили у Београд. По свему судећи, дошли су и нешто раније јер се 20. јануара 1923. рађа њихов први син Александар.

1 Државни архив Руске Федерације, Ф. Р-6792. Карт.П.Д. 4176 - из Антанасијевић, Рађеновић 2018: 51-54. 
Настањују се у Призренској улици број 6. и Анатолиј Иванович заједно са још двојицом руских професора исте године покреће издавачко предузеће Народна просвета. ${ }^{2}$

У Пријави за град Београд коју је Прицкер попунио 10.04.1924. наводи се да је он по занимању власник издавачког предузећа Народна просвета, југословенског држављанства, рођен 17/30. новембра 1897., у Ростову на Дону, од оца Ивана (преминулог) и мајке Александре, рођене Славине (преминуле); православне веороисповести са пребивалиштем у Београду (Југославија). У напомени исте пријаве налазимо податак да је он 1929. променио презиме и користећи патроним, добио србизовану варијанту имена - Анатолије Ивановић. У суштини, ова пријава је била евиденциони картон становања од почетка његовог боравка у Београду све до касније, поновне емиграције - у Јужну Америку. ${ }^{3}$

Како у писаној и сачуваној документацији постоје његове изјаве о месту рођења, тим се податком и служило - истина у ретким записима о њему: рецимо у пријави, како смо већ навели, Анатолије Ивановић исписује да је рођен у Ростову на Дону (Русија), затим у документу Основни подаци који је испунио, а који се односи на отварање штампарије, такође наводи Ростов на Дону као место рођења.

Међутим, испоставиће се да место рођења Анатолија Ивановича није било тако једноставно утврдити, као и да није оно које он сам наводи у извесним документима. Наиме, при хапшењу и испитивању његовог сина Александра 19.4.1944., у затвору на Дедињу, имамо Александрову изјаву да му је: отаи Карим мајка Српкиња која исто тако потиче из аријске обитељи: ${ }^{4}$ на истом месту тврди да су његовог оца већ 1941. испитивали о свом пореклу, а да се исправе о томе налазе делом код адвоката Vjekoslava Kisowez (у Београду, улица краља Фердинанда бр. 2, а да се други део исправа налази код Катарине Рајтер (улица Милутина Бојића бр. 8), иначе гувернанте породице Ивановић од рођења њиховог другог сина Николе, 1928. Знатно касније, при започињању поступка рехабилитације Анатолија Ивановича, адвокат Предраг Савић 2014. упутио је допис конзуларном одељењу амбасаде Руске Федерације у Републици Србији у нади да ће добити Анатолијев извод из матичне књиге

${ }^{2}$ Архив Југославије, Извештај Одељења опште полиције Управе града Београда, Ф. 74, ф.20-1 из Антанасијевић, Рађеновић 2018.

3 Пријава пребивалишта са подацима, Историјски архив Београда, УГБ, Централна пријавница - Картотека грађана пријављених у Београду, 1924.

${ }^{4}$ Наиме, Кримски Караити, Кримкарајлари или Караји су кримски Јевреји следбеници караитског јудаизма. Употребљавају караимски језик који припада кипчачкој грани туркијске породице језика. Агенција за утврђивање порекла и породице је установила да се са гледишта немачког закона Караими не могу сматрати Јеврејима. Писмо Канцеларије за истраживање сродства Pajха (нем. Reichsstelle für Sippenforschung) званично је наредио: „Караитска секта се не може сматрати јеврејском верском заједницом на основу параграфа 2, тачке 2 . првог закона о стицању држављанства. Међутим, не може се утврдити да су Караими у целини крвно повезана група, јер се расна категоризација појединца не може одредити без његовог личног порекла и расних карактеристика..." YIVO archives, Berlin Collection, Occ E, 3, Box 100, letter dated January 5,1939 . Вероватно је Александар био упућен у то па је желео да себе спаси том тврдњом. 
рођених, иначе нужан документ у свим поступцима и процесима. Одговор надлежног одељења је био негативан, образложен тиме да нису у могућности да приме процедуру због непрецизности и недостатка података. Међутим, након утврђивања правог места рођења Анатолија Ивановича постало је јасно зашто поменуте установе и нису биле у могућности да одговоре на захтев адвокатске канцеларије Савић.

Такође, истражујући грађу за стварање и постављање оригинале изложбе: Руски стрип Краљевине Југославије (Антанасијевић, Рађеновић 2018), а чији је део био и часопис Стрип Анатолија Ивановича Прицкера, проф.др Ирина Антанасијевић, професор на Катедри за славистику Београдског универзитета, један од аутора изложбе и каталога, обратила се Дому руске дијаспоре у нади да ће из Ростова на Дону добити извод из матичне књиге рођених Анатолија Ивановича, међутим и у овом случају одговор надлежних институција је био негативан. Упорним истраживањем проф.др Ирина Антанасијевић је августа 2019. дошла до значајног податка да је Анатолиј Иванович Прицкер, по свему судећи, рођен заправо на Криму, у месту Каховка. Отац, Јона Прицкер (Іона Прицкеръ), по занимању је био апотекар. У новинама Таврические губернские ведомости (№ 23 от 18.03.1916. Четвертая очередь. С 19-го по 24-е сентября 1916) налази се публикација у којој се помиње Јона Прицкер као почасни грађанин:

«От временной комиссии для составления списков присяжных заседателей по Днепровскому уезду публикуется список лиц, избранных в очередные и запасные присяжные заседатели по Днепровскому уезду на шесть очередей 1916 года для участия в заседаниях уголовного отделения Херсонского Окружного Суда, имеющих быть в гор.Алешках:

Четвертая очередь

С 19-го по 24-е сентября $1916_{1}$

Очередные:

(...)

Обревко Иван Иванович - купец; Онищенко Федор Дмитриевич - казак

Поляница Дмитрий Юрьевич - крестьянин;

ПРИЦКЕР Иона Давидович - личн.почетн.гражданин

Рудь Андрей Климович - крестьянин“ ( Таврические губернские ведомости 1916)".

1927. Анатолиј Иванович указом краља Александра Карађорђевића ${ }^{5}$ постаје српски држављанин и тај документ, уместо траженог извода, послужиће касније као нужан почетни доказ у процесу рехабилитације и оправдања доброг имена и гласа овог човека који је након Другог светског рата означен као неподесан, имовина му је конфискована, док је он са породицом био принуђен на поновну емиграцију.

Делатност Анатолија Ивановича примарно је била усмерена на рад издавачке куће која му је убрзо по стварању, а захваљујући успешној пословној стратегији,

${ }_{5}^{5}$ Службене новине Краљевине Срба, Хрвата и Словенаца. Година IX. - 1927. - Број 138. 23. јуни, четвртак, Београд. 
донела велики углед и истовремено обезбедила замашну финансијску стабилност. Као амбициозан човек који је умео да вешто усагласи своје послове са законима тржишта, Анатолиј Иванович убрзо је проширио своју делатност на начин који му је највише погодовао, те је 1930. отворио штампарију за потребе своје издавачке куће. 1930. на претходно упућени захтев од Индустријске коморе добио је одобрење о отварању и раду штампарског предузећа. Министарство Трговине и Индустрије Краљевине Југославије, 4. новембра 1931. издало је Решење на основу комисијског извештаја о прегледу штампарије и књиговезнице којим се Анатолију Ивановичу одобрава рад исте. Прва адреса штампарије и књиговезнице била је улица Јованова бр. 35. Годину дана касније, 18. септембра 1932., комесар Министарства трговине и индустрије за град Београд издаје му Дозволу за рад. ${ }^{6}$

Нешто касније, 1936., видимо да је седиште предузећа измештено и да се налази у дворишној згради на Обилићевом венцу бр.5. Бројеви телефона и скраћена телеграфска адреса биле су: 22-236, 22-351; Нарпрос Београд. Зграда на Обилићевом венцу замишљена је по веома модерном концепту, у њој се, поред изузетно добро опремљене штампарије која је била смештена у приземљу, на првом спрату налазила и стамбена јединица породице Прицкер. Штампарија је била савремено опремљена, састојала се из три одељења: слагачнице, стереотипије и машинске сале и имала је између 18 и 20 радника. Радно време је било стално, осмочасовно и у њој су се штампале углавном књиге и илустровани листови, али је наведено да би у случају рата штампарија могла да производи све ствари које спадају у штампарске послове у количини максималног капацитета при осмочасовном раду. Своје производе штампарија није извозила у иностранство, није имала отпадака нити је уживала посебне погодности од државе или других јавних самоуправних тела (субвенције, концесије, повластице, трошарински попуст, рефакције за транспорт итд).

Отварањем фабрике Дрвопродукт Умка, нешто касније, крајем 40-тих година, Анатолиј Иванович осведочава изузетне пословне и практичне вештине, а тиме што је фабрика производила све врсте лепенке и картона успео је да успешно обједини компатибилне делатности. Из свих извора јасно се види да је фабрику

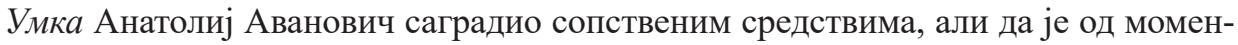
та добијања дефинитивне дозволе за рад, 1939. године, фабрика у његовом власништву радила само нешто више од две године и да му убрзо након окупације бива одузета. ${ }^{7}$ У картону Министарства народне привреде (отсек за статистику индустрије и занатства, датум: 27. XI 1942), у табели коју попуњава министарство, налазе се подаци за фирму Дрвопродукт Умка. Овај документ из 1942. сведочанство је о већ одузетој имовини Анатолија Ивановича, јер је у првом одељку, са захтевом како гласи тачан назив фирме, испуњено: „UMKA fabrika hartije i lepenke Stevan Kottas, док је само годину дана раније, 5. априла 1941,

${ }^{6}$ Архив Југославије. Краљевина Југославија, МИНИСТАРСТВО ТРГОВИНЕ И ИНДУСТРИЈЕ; индустријско-занатско одељење; III. Бр.36.403. БЕОГРАД Фонд бр. 6, 1932 Фасц. бр.616 - Дозвола Бр.6843.

7 Архив Југославије, Картон Министартва народне привреде, Отсек за статистику индустрије и занатства, Фонд бр. 6, Досије: 3904/01 
за власника уписан Anatolije I. Ivanović". ${ }^{8}$ Из истог документа сазнајемо да је Умка у периоду од 6. априла 1941 год. до 1. новембра 1942. године радила за трговачка и индустријска предузећа, према одобрењима Централе за хемијске производе - дакле, док је била у власништву Анатолија Ивановича, Умка није радила за потребе окупатора, док је од преузимања власништва фабрике у власништво Стевана Котаса то већ сасвим извесно.

Анатолиј Иванович Прицкер припадао оном најређе сретаном профилу људи који су поред своје пословне умешности, довитљивости и памети примарно тежили да осете дух и потребе културе свог времена. Чињеница је да су пословна умешност и виспреност Анатолија Ивановича доносили и велике финансијске приливе али према начину организације његове издавачке куће, одабиру сарадника и начину на који је Народна Просвета функционисала све до окупације Београда видимо да материјално богаћење није било ни примарни, нити његов најважнији циљ. Дабоме, у људској је природи, а нашем српском менталитету свакако блиска, сумња према искреној општој користи и чињењу, нарочито онда када постоји и посведочена озбиљна зарада приде, те је сасвим јасно да је и делатност Анатолија Ивановича морала подлећи суровом суду средине и времена.

У обимној студији о руској емиграцији Остоја Ђурић наводи за нас врло индикативан податак:

„Прицкер је 1926. године у Београду (Призренска бр.2) заједно са још два руска професора добио дозволу да оснује издавачко предузеће Народна просвета. Из једног поверљивог акта Управе града Београда, који је претходио одобрењу дозволе за рад, види се да је он дошао у Југославију 1920. године, да се настанио у Новом Саду, где се и оженио девојком из месне породице, те да се већ окушао заједно са још два Руса у издавању „неких литерарних књига“, да је поштен и уљудан човек итд“ (Ђурић 1990: 226).

Акт који се помиње у студији је Акт.Пов. бр.421 од 10.03. 1926. Архив Југославије под: Двор $\Phi$ 20-AJ, 33. Из овог документа сасвим је јасно да је Анатолиј Иванович праћен од тренутка када је отпочео издавачку делатност и да је о њему поднет извештај надлежним органима. Наиме, велика је вероватноћа да се о Анатолију Ивановичу све време његовог боравка у Југославији водио тајни досије, тачније, да је само редовно допуњаван од првог Пов. Акта који смо навели. С друге стране, у то време било је подоста домаћих шпијуна који су све време радили за окупаторе и раскривени су када је рат отпочео. Познат је случај Милана Брајера, по народности Немца, који је након Првог светског рата остао у Србији и за кога се тек 1941. након окупације Београда сазнало да је био немачки шпијун. Био је члан Књижарског удружења, а од 1931. и секретар, библиотекар и уредник Гласника књижара. Дакако, сасвим је извесно да су информације о многим успешним људима - њиховој имовини, пословима и породицама, обилато биле достављане непријатељима Србије, што је омогућило висок степен њихове оперативности у каснијим злоделима.

Уочи бомбардовања Београда, ваљда предосећајући трагичан крај, Геца Кон се с породицом склонио у Врњачку Бању, у хотел Србија. Међутим, кад је рат по-

\footnotetext{
${ }^{8}$ Архив Југославије, Фонд бр. 6 Досије: 3904/01
} 
чео, ту је и ухапшен и према већини сведочења пребачен у логор на Сајмишту, где му се губи сваки траг (Старчевић 2011: 75-83). ${ }^{9}$ Анатолиј Иванович као познати издавач, индустријалац и угледан грађанин, приде ожењен рођаком Гаврила Принципа, несумњиво је био део сличних шпијунско-издајничких извештаја. Након окупације он се склања у Мађарску заједно са супругом Крунославом и млађим сином Николом, а из докумената смо се могли уверити да му је имовина конфискована и дата фолксдојчеру Стевану Котасу. Старији син Александар, међутим, остаје у Београду на адреси Милутина Бојића бр.8. У време немачке окупације Београда, Александар Ивановић, старији Анатолијев син, имао је свега 18 година и био је свршени матурант Дома краља Александра на Дедињу.

1943. он отпочиње приватан посао - трговину дрветом, и у исто време бива осумњичен за везе са покретом Драгољуба Драже Михаиловића као један од његових присталица и финансијера. Из истог разлога је марта месеца ухапшен (претходно сасвим сигурно праћен) са вероватном намером да буде ликвидиран. Након испитивања, марта месеца 1944., Александар Ивановић је покупљен (abgeholt) - ухапшен (13.4.1944.). О његовом третману у затвору нема документованих података. У документацији логора на Бањици која се чува у Историјском архиву Београда постоје подаци о заточеништву Александра Ивановића - уписан је у књигу бр. 8 под регистарским бројем 21484, по занимању:

авитуријант; ожењен, отаи једног детета, са местом пребивалишта у Београду, улииа Богићева број 8. 17.април је датум довођења у логор; доведен од стране СС јединииа; датум пуштања из логора је 15.мај 1944. Гестапо. ${ }^{10}$

Александар је волшебно пуштен на слободу 16.5.1944. са одређеним захтевима. Цитирамо документ из полиције са датумом 13.4.1944. Овај документ из логора Дедиюе сведочанство је о његовом боравку и отпусту из истог:

9 Један од најугледнијих српских књижара и издавача - Геца Кон, рођен је 2.августа 1873. После завршене гимназије, први посао налази у књижари и антикварници код Фридриха Бреслауера, а потом седам година проводи код новосадског издавача и књижара Арсе Пајевића. Геца Кон отвара своју књижару 1901. - исте године када је покренут и Српски књижевни гласник - часопис чији је оснивач био Богдан Поповић. Његова књижара је у неколико наврата мењала адресе али се увек налазила у Кнез Михајловој улици. Она је била место окупљања најугледнијих личности из књижевног и јавног живота Србије (међу њима су били Слободан Јовановић, Бранислав Нушић, Милош Црњански, Јаша Продановић и многи други) и на тај начин ова књижара имала је далекосежан културни утицај. Због објављеног календара Ратник, којим се славила победа српске војске над аустроугарском, Кон је био ухапшен и провео је три године у логору Нежидер (Мађарска). Након основања Кьижжарског удружења 1921. Кон је изабран за потпредседника и био је једна од најактивнијих личности српског књижарства. Након 35 година рада, његово издаваштво досегло је 2.766 наслова. Његова издавачка делатност обухватала је све научне области, књижевност, књижевну критику (Скерлић, Поповић) али и велики број уџбеника. Међу најважније едиције спадају: Златна књига, Школски писци, филозофска библиотека Каријатиде.

${ }^{10}$ Историјски архив Београда, Bds I-370. 


\section{Z a p is n i k}

IV 4 b Gr.

Beograd, dne 15.maja 1944.

Iz logora . .Dędinj.e. predveden

Izjavljuje. . Ålẹksandẹr. I V.A. N. O. Y I C.

Sledeće:

Na stvar.

Saopšteno mi je da se puštam na slobodu.

Opomenuli su me, o tome, da nesmijem drugim osobama

pričati ništa, što sam vidio i čuo za vreme moga zatvora,

jer inaće moram računati sa najstrožijim policijskim merama.

Neću vršiti nikakvu političku niti protu državnu delatnost.

Sve stvari i novac, koji mi je oduzet prigodom moga

Hapšenja, izručeno mi je u redu.

Ja sam sve razumio. Nakon moga otpuštanja stanovat ću

U. Bẹogrạdụ uliça. Mịluținạ Bojiç̣a br. 8.

Pročitano $\begin{gathered}\text { odobreno } \\ \text { IWAN O V I T S C H Aleksander }\end{gathered}$
Zaključeno:
GROSSER s.r
SS-Scharfuehrer (Историјски архив Београда, Фонд. Вds I - 370)

Из бројних разговора о иследним процесима Александра Ивановића, које смо водили са београдским адвокатом Предрагом Савићем, који је водио процес рехабилитације (а сада и реституције) Анатолија Ивановича, његово замашно адвокатско искуство дало нам је подстицај и приличну увереност да је целокупан иследни процес против Александра исконструисан, тачније, да је слобода коју је Александар Ивановић добио 13.5.1944. напросто купљена. ${ }^{11}$ Наиме,

${ }^{11}$ Адвокатска канцеларија Савић у својој дугогодишњој и веома успешној пракси успела је да рехабилитује више официра Југословенске војске у Отаџбини, Инфорбировце са Голог отока, индустријалце, трговце, апотекаре, власнике издавачких кућа и штампарија али и појединце који су осуђивани из политичких побуда за време Слободна Милошевића. Рок за подношење захтева за рехабилитацију пред српским судовима истекао је 15.12.2016. Поједине адвокатске предмете и случајеве Предраг Савић преточио је у веома занимљива и корисна штива, а случај дубровачког госпара др Мата Грацића прерастао је у књигу. Многи његови текстови објављени су у Политици, серијалу Азбучник идентитета, на порталу Тамо далеко и штампаном издању гласила Српски глас у Аустралији. Један од најзанимљивијих текстова Предрага Савића посвећен је управо Анатолију Ивановичу Прицкеру (Три егзила 
тешко је без икакве сумње разумети и прихватити да је Александар Ивановић имао само невероватну срећу да га Гестапо као сина познатог индустријалца коме су одмах по окупацији одузели Дрвопродукт, који је праћен годинама уназад, пусти на слободу након месец дана затвора, а да је при том вођен и иследни процес у коме је Александар првенствено био оптужен за финансирање покрета Драже Михаиловића са којим, подсетићемо се, окупатор није водио никакву врсту преговора. Премда Гестапоу нису били потребни никакви ваљани докази за ликвидацију, очито је да ни Гестапо није био имун на добру и уносну трговину, те су извесни челни људи пристали на велику откупнину Александровог живота.

Његов случај овде наводимо јер он имплицира да је један од важних разлога што се у поратним годинама о Анатолију Ивановићу ћутало (готово да нема помена о раду издавачке куће Народна просвета) је чињеница да је његов старији син Александар био припадник и/или финансијер Равногорског покрета. Како већ знамо, потоњем дугогодишењм политичком мејнстирму није одговарала та оријентација и уверени смо да је цензура власти била значајан мотив дугог прећуткивања овог важног српског међуратног издавача. По свршетку рата, након неуспелог покушаја да Комисији за ратну штету пријави отшету - уништену и отету имовину, и нажалост, подучен судбинама бројних суграђана, Анатолиј схвата да је једини начин да преживе - поновни егзил. Преко Италије он се са породицом склања у Јужну Америку - прво у Венецуелу, а потом у Бразил.

Анатолиј Иванович Прицкер умро је у Сао Паолу (Бразил), 26. јануара 1954., у Институту Паулиста, од инфаркта миокарда, колапса периферних крвних судова. Кремиран и сахрањен на гробљу Араса (адреса у Бразилу: Ав. Гуаруљос, 1023). Никола, Анатолијев други син је, нажалост, око 1950. године нестао под неразјашњеним околностима.

Процес рехабилитације Анатолија Ивановића започет је иницијативом његовог сина Александра Ивановића, који је замолио свог дугогодишњег пријатеља (сада преминулог) др Ђорђа Лукачевића, иначе председника реуматолога Србије, да отпочне процес рехабилитације. Наиме, 10.5.2006. Луис (Александар) Ивановић Ерфурт, с тадашњим пребивалиштем у Каракасу (Венецуела), преко пуномоћника, поменутог доктора Ђорђа Лукачевића из Београда, поднео је Републичкој дирекцији за имовину Републике Србије пријаву одузете имовине, (број: 462-4831/2006-02) сагласно Закону о пријављивању и евидентирању одузете имовине. Адвокат Предраг Савић, коме је, како смо већ навели, поверен поступак рехабилитације Анатолија Ивановича Прицкера, у књизи Искорак ка правдипише да су поступци рехабилитације у Србији постали актуелни средином ове деценије jep је без њих немогуће пред Агенцијом за реституцију повратити конфисковану имовину. „Зато су, пише он, судови затрпани захтевима за рехабилитацију људи који су из политичких, верских, националних или идеолошких разлога лишени живота, слободе или других права током комунистичког режима (Савић 2019).

Адвокати Предраг Савић и Александар Ђурић су 2012. од потомака Анатолија Ивановича Ивановић де Саломон Валерије, Ивановић Ерфурт Луиса и Ива-

Анатолија Ивановича) објављен сада и у књизи Искорак ка правди, која представља репрезентативна постигнућа ове адвокатске канцеларије. (Савић 2019) 
новић Суарез Мариа Мартина) добили специјално овлашћење да поднесу захтев за судску рехабилитацију Анатолија Ивановича и да их заступају у предметном поступку рехабилитације пред Вишим судом у Београду, и по потреби и жалбеним поступцима пред Апелационим судом у Београду са правом подношења редовних и ванредних правних лекова и уставне жалбе. Именовани адвокати су такође били овлашћени и за подношење захтева за враћање одузете имовине и обештећење по основу закона о враћању одузете имовине и обештећењу. Почетком 2014. отпочета је рехабилитација Анатолија Ивановича, при чему су уредно поднети неопходни докази и образложење за покретање овог процеса. У образложењу је, првенствено, наведен значај рада издавачке куће Народна просвета коју је Анатолиј покренуо по доласку у Србију, а потом и мишљење зашто је постао, заједно са својом породицом, жртва политичко-идеолошког обрасца нове комунистичке власти:

„Неопростив је био његов друштвени углед у старој Југославији и имовина коју је поседовао. Политичко-идеолошки прогон овде има јасан циљ одузимање велике и вредне имовине“ (Савић 2019: 80-81). ${ }^{12}$

Анатолиј Иванович Прицкер рехабилитован је 2016. У току је поступак реституције његове имовине.

\section{Цитирана литература}

Антанасијевић, Ирина, Ранка Рађеновић. Руски стрип Краљевине Југославије. Каталог изложбе. Београд: Друштво за очување наслеђа руске емиграције Архив АЛТЕРА уз подршку Министарства културе информисања Републике Србије, 2018.

[Antanasijević, Irina, Ranka Rađenović. Ruski strip Kraljevine Jugoslavije. Katalog izložbe. Beograd: Društvo za očuvanje nasledja ruske emigracije Arhiv ALTERA uz podršku Ministrastva kulture informisanja Republike Srbije, 2018]

Ђурић, Остоја. Руска литерарна Србија. Београд: Дечје новине, Српски фонд словенске писмености и словенских култура, 1990.

[Djurić, Ostoja. Ruska literarna Srbija. Beograd: Dečje novine, Srpski fond slovenske pismenosti i slovenskih kultura, 1990]

Старчевић, Велимир. Старо српско књижарство. Београд: Сведоци епохе, Службени гласник, 2011.

[Starčević, Velimir. Staro srpsko knjižarstvo. Beograd: Svedoci epohe, Službeni glasnik, 2011]

Савић, Предраг. Искорак ка правди. Београд. Народна просвета, 2019.

[Savić, Predrag. Iskorak ka pravdi. Beograd: Narodna prosveta, 2019]

12 Захтев за рехабилитацију пок. Анатолија Ивановића из бив. из Београда у три примерка са пуномоћјем и прилозима, Виши суд у Београду, од дана: 28.02.2014. Адвокатска канцеларија Савић, ул.Албанске споменице 1, 1100 Београд 


\section{Архивски извори}

Архив Југославије, Извештај Одељења опште полиције Управе града Београда, Ф. 74, ф.20-1 из Антанасијевић, 2018.

[Arhiv Jugoslavije, Izveštaj Odeljenja opšte policije Uprave grada Beograda, F. 74, f.201 iz Antanasijević, 2018.]

Архив Југославије, Краљевина Југославија, Фонд бр. 6, 1932 Фасц.бр.616 - Дозвола Бp. 6843]

[Arhiv Jugolavije, Kraljevina Jugoslavija, Fond br. 6, 1932 Fasc.br.616 - Dozvola br. 6843]

Архив Југославије, Картон Министартва народне привреде, Отсек за статистику индустрије и занатства, Фонд бр. 6, Досије: 3904/01

[Arhiv Jugoslavije, Karton Ministarstva narodne privrede, Otsek za statistiku industrije i zanatstva, Fond br. 6, Dosije: 3904/01]

Државни архив Руске Федерације, Ф. Р-6792. Карт.П.Д. 4176 из Антанасијевић, 2018.

[Državni arhiv Ruske Federacije, F. R - 6792. Kart.P.D. 4176 iz Antanasijević, 2018]

Историјски архив Београда: РЕШЕњЕ. Краљевина Југославија, МИНИСТАРСТВО ТРГОВИНЕ И ИНДУСТРИЈЕ; индустријско-занатско одељење; III. Бр.36.403. БЕОГРАД.

[Istorijski arhiv Beograda: REŠENJE. Kraljevina Jugoslavija, MINISTARSTVO TRGOVINE I INDUSTRIJE; industrijsko-zanatsko odeljenje; III. Br. 36.403. BEOGRAD.

Историјски архив Београда: Уверење о документацији Логора на Бањици, Фонд. Bds I - 370.

[Istorijski arhiv Beograda: Uverenje o dokumentaciji Logora na Banjici, Fond. Bds I370]

Историјски архив Београда. Пријава пребивалишта са подацима, УГБ, Централна пријавница - Картотека грађана пријављених у Београду, 1924.

[Istorijski arhiv Beograda. Prijava prebivališta sa podacima, UGB, Centralna prijavnica Kartoteka građana prijavljenih u Beogradu, 1924]

YIVO archives, Berlin Collection, Occ E, 3, Box 100, letter dated January 5, 1939.

\section{Остали извори}

Захтев за рехабилитацију пок. Анатолија Ивановића из бив. из Београда у три примерка са пуномоћјем и прилозима, Виши суд у Београду, од дана: 28.02.2014. Адвокатска канцеларија Савић, ул.Албанске споменице 1, 1100 Београд.

[Zahtev za rehabilitaciju pok. Anatolija Ivanovića iz biv. Iz Beograda u tri primerka sa punomoćjem i prilozima, Viši sud u Bogradu, od dana: 28.02.2014. Advokatska kancelarija Savić, ul. Albanske spomenice 1100 Beograd]

Републичка дирекција за имовину Републике Србије - пријава одузете имовине, Образац ПОИ, у Београду, 10.маја 2006.

[Republička direkcija za imovinu Republike Srbije - prijava oduzete imovine, Obrayac POI, u Beograu, 10. maja 2006]

Републичка дирекција за имовину Републике Србије - потврда о евидентирању имовине, број: 462-4831/2006-02 од 15.маја 2006. Београд. 
[Republička direkcija za imovinu Republike Srbije - potvrda o evidentiranju imovine, broj: 462 - 4831/2006-02 од 15. maja 2006. Beograd.

Службене новине Краљевине Срба, Хрвата и Словенаца. Година IX. - 1927. - Broj 138. 23. јуни, четвртак, Београд.

[Službene novine Kraljevine Srba, Hrvata i Slovenaca. Godina IX. - 1927. - Broj 138. 23. juni, četvrtak, Beograd]

Таврические губернские ведомости № 23 от 18.03.1916. Четвертая очередь.С 19-го по 24-е сентября 1916.

[Tavričeskie gubernskie vedomosti. Četvertaâ očered'. S 19-go po 24-e sentâbrâ 1916]

\section{Ивана Божович}

\section{АНАТОЛИЙ ИВАНОВИЧ ПРИЦКЕР: БИОГРАФИЯ}

\section{Резюме}

В статье рассматриваются вопросы, связанные с обстоятельствами жизни и деятельности А.И. Прицкера, молодого русского эмигранта в Королевстве сербов, хортватов и словенцев, основателя издательского предпрития Народна просвета. Работа написана по архивным материалам, которые впервые вводятся в научный оборот (Архив Югославии и Исторический архив Республики Сербии).

Ключевые слова: Анатолий Иванович Прицкер, Народна просвета, юридическая фирма «Савич». 